\title{
PENGARUH GAYA HIDUP, PERCEIVED BENEFIT, DAN PERCEIVED RISK TERHADAP NIAT MENGGUNAKAN KARTU KREDIT DI INDONESIA
}

\author{
Ni Made Puspa Dewi ${ }^{1}$ \\ Ni Made Asti Aksari \\ ${ }^{1,2}$ Fakultas Ekonomi dan Bisnis Universitas Udayana, Bali, Indonesia \\ email: puspadewi1504@gmail.com
}

\begin{abstract}
ABSTRAK
Kartu kredit menjadi salah satu alat pembayaran nontunai yang diminati masyarakat, ditandai dengan terus meningkatnya jumlah kartu yang beredar, volume dan nominal transaksi kartu kredit di Indonesia. Penelitian ini bertujuan untuk menjelaskan pengaruh gaya hidup, perceived benefit, dan perceived risk terhadap niat menggunakan kartu kredit di Indonesia. Sampel yang digunakan berjumlah 140 orang diambil dengan metode purposive sampling. Pengumpulan data dilakukan dengan menyebarkan kuesioner secara online dan teknik analisis data yang digunakan adalah analisis regresi linier berganda. Hasil penelitian menunjukkan gaya hidup dan perceived benefit berpengaruh positif terhadap niat menggunakan kartu kredit, sedangkan perceived risk berpengaruh negatif terhadap niat menggunakan kartu kredit. Perceived benefit dan perceived risk menjadi faktor terkuat yang mempengaruhi niat menggunakan kartu kredit, sehingga disarankan bagi pihak bank untuk memberikan pemahaman mengenai manfaat dan risiko dari kartu kredit kepada konsumen melalui edukasi berupa sosialisasi atau seminar.

Kata kunci: gaya hidup, perceived benefit, perceived risk, niat menggunakan
\end{abstract}

\begin{abstract}
Credit card is a non-cash payment instrument that are desirable to the society, this is showned by the increasing number of credit cards used by the society, and the amount of transactions done using credit card in Indonesia. This study aims to explain the influence of lifestyle, perceived benefit, and perceived risk on the intention to use credit card in Indonesia. By using purposive sampling method, a sample of 140 respondents were used in this study. Data was collected through online questionnaires and analysed using multiple linear regression analysis. Study results show that lifestyle and perceived benefit has a positive effect on the intention to use credit card, while perceived risk has a negative effect on the intention to use credit card. Perceived benefit and perceived risk are the strongest factors that influence the intention to use credit card, therefore it is recommended for banks to educate consumers about the benefits and risks of using credit cards through seminars and other educational events.

Keywords: lifestyle, perceived benefit, perceived risk, the intention to use
\end{abstract}




\section{PENDAHULUAN}

Kemajuan teknologi dalam sistem pembayaran menggeser peranan uang tunai sebagai alat pembayaran ke dalam bentuk pembayaran non tunai. Penggunaan uang tunai sebagai alat pembayaran dirasakan mulai menimbulkan masalah terutama tingginya biaya cash handling, risiko perampokan/pencurian, kepraktisan serta uang palsu menjadi beberapa penyebab masyarakat mulai meninggalkan penggunanan uang tunai dan beralih menggunakan alat pembayaran non tunai yang lebih efisien dan ekonomis. Menanggapi hal tersebut, perkembangan penggunaan alat pembayaran non tunai mendapat perhatian yang serius dari pemerintah khususnya Bank Indonesia dalam memastikan bahwa sistem pembayaran non tunai yang digunakan oleh masyarakat dapat berjalan secara aman, efisien dan handal mengingat perkembangan pembayaran non tunai diharapkan dapat mengurangi beban penggunaan uang tunai dan semakin meningkatkan efisiensi perekonomian dalam masyarakat (Tim Inisiatif BI, 2006).

Pembayaran non tunai umumnya dilakukan tidak dengan menggunakan uang sebagai alat pembayaran melainkan dengan cara transfer antar bank ataupun transfer intra bank melalui jaringan internal bank sendiri. Selain itu, pembayaran non tunai juga dapat dilakukan dengan menggunakan kartu sebagai alat pembayaran (Pramono dkk., 2006). Salah satu alat pembayaran dengan menggunakan kartu yang populer di masyarakat adalah kartu kredit (credit card). Menurut Peraturan Bank Indonesia Nomor 14 Tahun 2012, kartu kredit merupakan Alat Pembayaran Menggunakan Kartu (APMK) yang dapat digunakan untuk melakukan pembayaran atas kewajiban yang timbul dari suatu kegiatan ekonomi, termasuk transaksi pembelanjaan dan/atau untuk melakukan penarikan tunai, dimana kewajiban pembayaran pemegang kartu dipenuhi terlebih dahulu oleh acquirer atau penerbit, dan pemegang kartu berkewajiban untuk melakukan pembayaran pada waktu yang disepakati baik dengan pelunasan secara sekaligus (charge card) ataupun dengan pembayaran secara angsuran.

Kartu kredit merupakan jenis APMK yang keberadaannya paling lama di Indonesia (Bank Indonesia, 2009). Kartu kredit mulai berkembang di Indonesia sekitar tahun 1980-an oleh Bank Duta yang bekerja sama dengan principal internasional VISA dan Master Card. Pada saat itu, kartu kredit yang dipasarkan masih bersifat konvensional dan hanya ditujukan untuk orang-orang kaya di Indonesia yang sering bepergian ke luar negeri (Lubis \& Lubis, 2012). Namun seiring dengan berjalannya waktu, kartu kredit mendapat respon positif dari masyarakat dengan terus mengalami peningkatan hingga saat ini baik dari segi jumlah kartu yang beredar, volume transaksi dan nominal transakasi kartu kredit seperti yang ditunjukan pada Tabel 1 .

Berdasarkan data pertumbuhan kartu kredit di Indonesia yang dikeluarkan oleh Bank Indonesia sampai dengan tahun 2018, menunjukkan adanya peningkatan aktivitas baik dari segi jumlah kartu, volume transaksi menggunakan kartu kredit, dan nominal transaksi kartu kredit di Indonesia, meskipun pada tahun 2017 jumlah kartu yang beredar mengalami penurunan namun penggunaannya (volume dan nominal transaksi) tetap terus meningkat. Peningkatan yang cukup signifikan ini menandakan kartu kredit masih begitu diminati oleh masyarakat sebagai alat pembayaran non tunai dalam kegiatan bertransaksi sehari-hari. 
Fenomena ini seolah menciptakan ladang bisnis baru bagi perbankan atau lembaga keuangan selain bank sebagai penerbit kartu kredit yang ditandai dengan gencarnya persaingan merebut nasabah pemegang kartu kredit yang dilakukan penerbit melalui upaya pemasaran, penambahan fitur, pemberian manfaat dan fasilitas diskon serta hal-hal lainnya (Bank Indonesia, 2009).

Tabel 1.

Pertumbuhan Kartu Kredit Di Indonesia

\begin{tabular}{cccc}
\hline Tahun & $\begin{array}{c}\text { Jumlah Kartu } \\
\text { Beredar }\end{array}$ & \multicolumn{2}{c}{ Transaksi Kartu Kredit } \\
\cline { 3 - 4 } & 16.043 .347 & $\begin{array}{c}\text { Volume } \\
\text { (Satuan Transaksi) }\end{array}$ & $\begin{array}{c}\text { Nominal } \\
\text { (Jutaan Rupiah) }\end{array}$ \\
\hline 2014 & 16.863 .842 & 254.320 .061 & 255.057 .458 \\
2015 & 17.406 .327 & 281.325 .840 & 280.543 .930 \\
2016 & 17.244 .127 & 305.052 .297 & 281.020 .518 \\
2017 & 17.275 .128 & 327.377 .665 & 297.761 .229 \\
2018 & 338.347 .867 & 288.136 .181 \\
\hline
\end{tabular}

Sumber: Bank Indonesia, 2019

Secara umum kartu kredit memiliki bentuk ukuran yang hampir mirip dengan kartu ATM, kartu debit atau kartu identitas serta model dan warna yang bervariasi. Terdapat beberapa karakteristik kartu kredit yang diterbitkan perbankan seperti chip pada kartu kredit yang selalu diletakkan di bagian depan sisi kartu, chip ini telah ditambahkan berbagai aplikasi yang dapat mengenkripsi data sehingga data dapat tersimpan lebih aman, nomor kartu yang terdiri atas 16 digit, nama pemegang kartu, nama penerbit kartu kredit, masa berlaku kartu kredit, logo jaringan kartu kredit, magnetic stripe yang masih dapat digunakan jika kartu kredit tersebut digunakan untuk bertransaksi di luar negeri, signature panel (tempat pembubuhan tanda tangan pemilik kartu pada kartu kredit yang dimiliki), nomor verifikasi yang terdiri atas tiga digit, alamat bank penerbit kartu kredit, dan nama/logo penerbit kartu kredit (Bank Indonesia, 2010).

Kartu kredit yang sesuai kebutuhan dan keinginan konsumen dapat dijadikan sebagai salah satu pendukung terbentuknya niat konsumen untuk menggunakan (Kirana \& Kerti Yasa, 2013). Konteks ini mengacu pada niat berbelanja dengan menggunakan kartu kredit yang dapat diartikan sebagai kecenderungan atau keinginan seseorang untuk melakukan transaksi dengan menggunakan kartu kredit (Alam, 2006). Menurut Jogiyanto (2007:116), niat adalah suatu keinginan untuk melakukan perilaku, niat itu dapat berubah-ubah sesuai dengan berjalannya waktu. Menurut Kotler \& Keller (2016:199), niat beli atau niat menggunakan merupakan salah satu fase dalam proses pengambilan keputusan bagi konsumen yang timbul setelah adanya suatu kebutuhan yang dirasakan oleh individu. Menurut Ferdinand (2014:188), niat konsumen untuk menggunakan suatu produk dapat diukur melalui beberapa indikator yakni, niat transaksional (kecenderungan atau keinginan seseorang untuk segera membeli/ menggunakan suatu produk), niat eksploratif (kecenderungan seseorang ingin 
mengetahui lebih dalam mengenai suatu produk), dan niat preferensial (perilaku seseorang yang memiliki preferensi utama terhadap suatu produk dan bersedia mengabaikan pilihan lain).

Tinggi rendahnya suatu niat untuk menggunakan kartu kredit dapat dipengaruhi oleh beberapa faktor-faktor tertentu. Menurut Kotler \& Keller (2016:179), perilaku pembelian konsumen dipengaruhi oleh faktor budaya, faktor sosial, dan faktor pribadi. Salah satu faktor pribadi yang memengaruhi niat konsumen untuk menggunakan kartu kredit adalah gaya hidup. Pertumbuhan kartu kredit di Indonesia yang cukup signifikan menunjukkan bahwa kartu kredit kini makin populer sebagai alat pengganti uang cash, bahkan telah menjadi bagian dari gaya hidup masyarakat modern di Indonesia (Lubis \& Lubis, 2012). Bernthal et al. (2005) mengungkapkan bahwa kartu kredit telah menjadi fasilitator gaya hidup seseorang. Tingginya persaingan bisnis kartu kredit, membuat beberapa bank menciptakan segmentasi pemegang kartu kredit sesuai dengan gaya hidup pemegang kartu atau affiliasi tertentu berdasarkan kebutuhan pemegang kartu seperti kartu kredit untuk komunitas tertentu, kartu kredit khusus travelling dan segmen khusus lainnya (Bank Indonesia, 2009).

Menurut Mowen \& Minor (2002:282), gaya hidup menunjukkan bagaimana orang hidup, bagaimana membelanjakan uangnya, dan bagaimana mengalokasikan waktu. Gaya hidup mengacu pada profil psikografis konsumen yang dapat dianggap sebagai gabungan berbagai kegiatan (activities), minat (interests), dan pendapat (opinions) (AIO) konsumen yang dapat diukur (Schiffman \& Kanuk, 2008:48). Gaya hidup mencerminkan nilai, norma, harapan, dan keinginan individu. Orang-orang menunjukkan identitas sosial mereka melalui gaya hidup (Rashidi, 2015).

Untuk mengidentifikasi hubungan spesifik antara sikap konsumen menyangkut gaya hidupnya dengan perilaku pembelian, Strategic Business Insights (SBI) melakukan inventaris psikologis yang disebut VALS 2 (Value and Lifestyle 2). Inventaris ini terbagi menjadi 8 (delapan) segmen, yaitu innovators, thinkers, believers, achievers, strivers, experiencers, makers, dan survivors. Wickramasinghe \& Gurugamage (2012) memaparkan terdapat lima faktor atau dimensi yang membentuk konstruk persepsi gaya hidup dari penggunaan kartu kredit, yaitu: hutang, peningkatan status sosial, peningkatan pengeluaran, fasilitas pembelian dan keyakinan atas kemampuan keuangan. Meskipun hutang pada suatu waktu dihindari tapi dari penelitian yang dilakukan menunjukkan bukti bahwa konsumen memberikan sikap yang positif terhadap kartu kredit dan penggunaannya.

Rahayu dkk. (2011) menyebutkan bahwa kartu kredit merupakan simbol gaya hidup. Kartu kredit memiliki kapasitas untuk mendorong gaya hidup seseorang. Kegiatan menggunakan kartu kredit dianggap bisa menunjukkan karakter, gengsi, dan keberhasilan ekonomi seseorang yang mengakibatkan gaya hidup diperkirakan dapat memengaruhi minat seseorang untuk menggunakan kartu kredit (Alam, 2006). Kartu kredit dapat meningkatkan status sosial penggunanya dengan mendapatkan akses fasilitas kelas utama dan layanan khusus di tempat yang telah ditunjuk oleh bank penerbit kartu kredit seperti pusat pembelanjaan, bandar udara dan pusat-pusat hiburan. 
Namun disisi lain, penggunaan kartu kredit masih dipandang secara negatif oleh beberapa kelompok masyarakat. Kartu kredit dianggap memiliki citra negatif yang mengubah gaya hidup seseorang menjadi lebih konsumtif dan berdampak pada bertambahnya beban finansial (Astari, 2016). Anggapan bahwa kartu kredit hanya untuk orang-orang berpendapatan tinggi (orang kaya) masih melekat pada benak sebagian besar masyarakat, sehingga apabila pihak bank menawarkan kartu kredit, mereka akan menghindar atau menolak penawaran tersebut dengan berbagai alasan, seperti takut hutang, menambah banyak biaya, hidup menjadi lebih boros, dan sebagainya (Rahayu dkk., 2011).

Seseorang perlu mengetahui dan mempertimbangkan apa keunggulan dan kekurangan dari penggunaan kartu kredit sehingga dapat digunakan secara maksimal dan memberi manfaat pada penggunanya (Gunawan \& Linawati, 2013). Hadirnya kartu kredit dalam kehidupan sehari-hari, masyarakat mempersepsikan manfaat dan risiko yang mereka dapat saat melakukan pembelian dengan menggunkan kartu kredit, yang kemudian memengaruhi niat beli konsumen itu sendiri. Manfaat yang dirasakan (perceived benefit) adalah kombinasi dari atribut fisik, atribut pelayanan dan dukungan teknis yang berhubungan dengan kegunaan dari produk atau jasa tersebut (Kirana \& Kerti Yasa, 2013). Perceived beneift merupakan tingkatan dimana pengguna percaya, bahwa dengan menggunakan sesuatu produk yang ditawarkan mereka akan merasakan manfaat yang didapat dari penggunaan produk tersebut (Andryanto, 2016).

Lee (2008) menyebutkan ada dua jenis utama dari perceived benefit, yang dapat dikategorikan sebagai manfaat langsung dan tidak langsung. Manfaat langsung mengacu pada keuntungan yang didapat langsung dan nyata yang akan dinikmati pelanggan dengan menggunakan perbankan online, sementara manfaat tidak langsung adalah keuntungan yang kurang nyata dan sulit diukur. Venkatesh \& Davis (2000) membagi perceived benefit menjadi empat dimensi yakni, improves job performance (dengan menggunakan sistem dapat meningkatkan kinerja individu), increases productivity (penggunaan sistem mampu menambah tingkat produktifitas individu), enhances effectiveness (penggunaan sistem mampu meningkatkan efektifitas kinerja individu), dan the system is useful (penggunaan sistem bermanfaat bagi individu).

Benefit yang terlihat jelas dari kartu kredit adalah kemudahan dalam bertransaksi sehingga seseorang tidak perlu membawa banyak uang tunai saat bepergian. Kartu kredit juga memberikan banyak penawaran menarik termasuk program diskon dan angsuran yang dapat meringankan beban konsumen dalam bertransaksi. Seiring dengan perkembangan teknologi informasi yang semakin pesat, kartu kredit dapat digunakan untuk melakukan pembayaran tagihan listrik, telepon, air, atau televisi berlangganan. Tagihan langsung didebet dari plafon kredit atas permintaan dan persetujuan pemegang kartu kredit, dengan begitu konsumen tidak perlu lagi antri untuk bayar dan tidak perlu takut terkena denda jika terlambat membayar (Gerai Info Edisi 23 Bank Indonesia, 2012).

Pada realitanya, berbagai manfaat dan keuntungan yang ditawarkan pihak bank tidak cukup meyakinkan dan mendorong seseorang untuk menggunakan kartu kredit. Beberapa kelompok masyarakat bahkan belum mengetahui dan memahami akan penggunaan kartu kredit, serta minimnya edukasi terkait 
penggunaan dan keunggulan yang dimiliki kartu kredit menjadi salah satu penyebab keengganan masyarakat menggunakan kartu kredit (Rochmawati, 2013). Disisi lain, risiko yang dirasakan (perceived risk) dalam penggunaan kartu kredit yang dinilai cukup tinggi menjadi salah satu penyebab hambatan dan keraguan seseorang untuk menggunakan kartu kredit (Disa \& Kesuma, 2016).

Menurut Kotler \& Keller (2016:200), niat dan keputusan konsumen untuk memodifikasi, menunda, atau menghindari keputusan pembelian sangat dipengaruhi oleh perceived risk. Kim et al. (2008) mendefinisikan risiko yang dirasakan (perceived risk) sebagai keyakinan konsumen tentang potensi hasil negatif yang tidak pasti dari transaksi online. Schiffman \& Kanuk (2008:170) mendefinisikan perceived risk sebagai ketidakpastian yang dihadapi para konsumen jika mereka tidak dapat meramalkan konsekuensi keputusan pembelian mereka.

Lee (2008) membagi perceived risk menjadi beberapa dimensi, yaitu: security/privacy risk (adanya potensi untuk kehilangan privasi dan keamanan informasi pribadi atas penggunaan suatu produk), financial risk (adanya kemungkinan pembelian dari suatu produk mengakibatkan kerugian secara finansial, ketidaksesuaian antara harga dengan produk yang dibeli, ketidakbijaksanaan dalam membeli barang, termasuk juga kemungkinan produk membutuhkan perbaikan atau penggantian, hilangnya uang karena salah membeli), social risk (adanya potensi seseorang untuk kehilangan status dalam suatu kelompok sosial akibat dari penggunaan suatu produk), time risk (risiko hilangnya waktu yang digunakan untuk mencari, membeli dan mempelajari penggunaan suatu produk jika produk tidak memenuhi harapan), perfomance risk (kemungkinan bahwa produk tidak dapat berfungsi seperti yang direncanakan dan gagal untuk memberikan manfaat yang diharapkan), dan pysical risk (kemungkinan bahwa produk yang dibeli dapat membahayakan keselamatan diri dan orang lain).

Sayono dkk. (2009) menyebutkan alasan utama seseorang menolak untuk memiliki kartu kredit adalah ketakutan berhutang. Citra negatif kartu kredit yang membuat seseorang selalu berhutang dan risiko berurusan dengan debt collector menjadi alasan seseorang menghindari penggunaan kartu kredit (Rochmawati, 2013). Selain itu, masalah keamanan menjadi salah satu faktor penyebab utama masyarakat menolak untuk menggunakan kartu kredit. Dari hasil evaluasi penggunaan kartu kredit, ditemukan permasalahan-permasalahan yang terkait dengan keamanan penggunaan kartu kredit seperti pembobolan kartu kredit oleh orang lain dan pembebanan biaya-biaya transaksi diluar sepengetahuan pengguna kartu kredit (Gerai Info Edisi 23 Bank Indonesia, 2012). Penelitian ini bertujuan untuk menjelaskan pengaruh gaya hidup, perceived benefit, dan perceived risk terhadap niat menggunakan kartu kredit di Indonesia.

Qing et al. (2012) membuktikan bahwa niat konsumen untuk membeli buah segar import di China secara positif dan signifikan dipengaruhi oleh gaya hidup. Nora \& Minarti (2016) dalam penelitiannya menjelaskan bahwa gaya hidup terbukti memiliki pengaruh terhadap niat pembelian. Suraputra \& Warmika (2017) menyatakan gaya hidup berpengaruh positif dan signifikan terhadap niat pembelian sepeda motor sport Honda di Kota Denpasar. Anggraini \& Soenhadji 
(2016) menjelaskan bahwa semakin tinggi gaya hidup seseorang maka kecenderungan menggunakan kartu kredit semakin kuat. Hasil berbeda ditemukan oleh Asbar (2014) yang dalam penelitiannya tidak menunjukkan adanya pengaruh yang signifikan gaya hidup terhadap penggunaan kartu kredit yang dijelaskan secara statistik dengan nilai critical ratio sebesar 0,126 dibawah $\pm 1,96$. Berdasarkan hasil empiris pada penelitian sebelumnya, maka hipotesis yang dapat diajukan dalam penelitian ini adalah:

$\mathrm{H}_{1}$ : Gaya hidup berpengaruh positif signifikan terhadap niat menggunakan

Amin (2007) membuktikan perceived benefit secara positif dan signifikan memengaruhi niat menggunakan mobile credit card. Lee (2008) memaparkan bahwa perceived benefit secara positif signifikan meningkatkan niat untuk menggunakan online banking. Zaidi et al. (2014) menyatakan perceived benefit berpengaruh positif signifikan terhadap niat belanja online. Andryanto (2016) juga menyatakan minat beli konsumen OLX.co.id dipengaruhi secara positif dan signifikan oleh perceived benefit. Berbeda dengan penelitian yang dilakukan oleh Cheema et al. (2013) yang menyatakan perceived benefit tidak berpengaruh signifikan terhadap niat belanja online. Ini berarti niat anggota sampel untuk berbelanja online bukan karena manfaat yang dirasakan namun karena alasan lain yang tidak disebutkan dalam penelitian. Berdasarkan hasil empiris pada penelitian sebelumnya hipotesis yang dapat diajukan dalam penelitian ini adalah:

$\mathrm{H}_{2}$ : Perceived benefit berpengaruh positif signifikan terhadap niat menggunakan

Kim et al. (2008) dalam penelitiannya menyatakan perceived risk memiliki pengaruh negatif dan signifikan terhadap niat pembelian. Sejalan dengan penelitian yang dilakukan oleh Juniwati (2014) yang menyatakan perceived risk berpengaruh negatif signifikan terhadap niat pembelian. Farzianpour et al. (2014) memaparkan bahwa perceived risk berpengaruh negatif signifikan terhadap penggunaan layanan perbankan online. Disa \& Kesuma (2016) menyatakan terdapat pengaruh signifikan dari variabel perceived risk terhadap niat pembelian. Quan \& Nam (2017) membuktikan bahwa faktor perceived risk berpengaruh negatif pada niat untuk menggunakan kartu kredit. Berbeda dengan penelitian Dewi \& Warmika (2016) yang menyatakan perceived risk berpengaruh positif dan signifikan terhadap niat menggunakan Mobile Commerce di Kota Denpasar, diikuti oleh penelitian Fernanda (2016) yang menyatakan perceived risk berpengaruh tidak signifikan terhadap niat pembelian. Berdasarkan hasil empiris pada penelitian sebelumnya hipotesis yang dapat diajukan dalam penelitian ini adalah:

$\mathrm{H}_{3}$ : Perceived risk berpengaruh negatif signifikan terhadap niat menggunakan

\section{METODE PENELITIAN}

Penelitian ini dilakukan di Indonesia yang terbagi menjadi 16 provinsi, yakni: Bali (44,3\%), Jawa Timur (15,7\%), DKI Jakarta $(13,6 \%)$, Sumatera Utara (4,3\%), Jawa Barat (3,6\%), Jawa Tengah (3,6\%), DIY (2.1\%), NTB (2,1\%), Sumatera Selatan (2,1\%), Kalimantan Timur (1,4\%), NTT (1,4\%), Sulawesi Tengah (1,4\%), Sulawesi Utara (1,4\%), Sumatera Barat $(1,4 \%)$, Sulawesi Selatan $(0,7 \%)$, dan Kalimantan Barat (0,7\%). Seluruh variabel yang dikaji beserta simbol dan indikator masing-masing disajikan secara ringkas pada Tabel 2. 
Populasi dalam penelitian ini adalah masyarakat atau warga negara Indonesia yang berusia minimal 17 tahun dan belum pernah menggunakan kartu kredit sebagai salah satu alat untuk melakukan transaksi perbankan yang belum diketahui jumlahnya. Sampel yang digunakan dalam penelitian ini berjumlah 140 orang. Pengambilan sampel penelitian ini menggunakan teknik non probability sampling, dengan cara purposive sampling. Kriteria sampel yang ditentukan dalam penelitian ini adalah 1) Usia minimal 17 tahun; 2) Belum pernah menggunakan kartu kredit.

Tabel 2.

Indikator Variabel Penelitian

\begin{tabular}{|c|c|c|c|c|}
\hline No. & Variabel & & Indikator & Sumber \\
\hline \multirow{4}{*}{1.} & & $\mathrm{Y}_{1.1}$ & Niat transaksional & \\
\hline & NIal Mienggunakan & $\mathrm{Y}_{1.2}$ & Niat eksploratif & Ferdinand (2014) \\
\hline & & $\mathrm{Y}_{1.3}$ & Niat preferensial & \\
\hline & Gava Hi & $\mathrm{X}_{1.1}$ & $\begin{array}{l}\text { Peduli personal image atau } \\
\text { citra diri }\end{array}$ & $\begin{array}{l}\text { Strategic Business Insights } \\
\text { (2015): Mowen \& Minor }\end{array}$ \\
\hline \multirow[t]{2}{*}{2.} & (X1) & $\mathrm{X}_{1.2}$ & Aktivitas & (2002); Wickramasinghe \& \\
\hline & & $\mathrm{X}_{1.3}$ & Opini & Gurugamage (2012) \\
\hline \multirow{5}{*}{3.} & & $\mathrm{X}_{2.1}$ & Improves job performance & \\
\hline & & $\mathrm{X}_{2.2}$ & Increases productivity & akkatesh \& Davis (2000) \\
\hline & Perceived Benefit & $\mathrm{X}_{2.3}$ & Enhances effectiveness & Lee (2008): Lestari dkk. \\
\hline & $(\mathrm{X} 2)$ & $\mathrm{X}_{2.4}$ & Cadangan dana & (2017) \\
\hline & & $\begin{array}{l}\mathrm{X}_{2.5} \\
\mathrm{X}_{2.6}\end{array}$ & $\begin{array}{l}\text { Fleksibel } \\
\text { Fasilitas pembelian }\end{array}$ & \\
\hline 4. & Perceived Risk $\left(\mathrm{X}_{3}\right)$ & $\mathrm{X}_{3.1}$ & Security/privacy risk & Lee (2008) \\
\hline
\end{tabular}

Sumber: Kajian penelitian sebelumnya

Data dikumpulkan dengan instrumen penelitian berupa kuesioner yang disebarkan kepada responden secara online melalui Google Form yang akan diukur dengan menggunakan skala Likert. Penelitian ini menggunakan validitas konstrak (constract validity). Setiap instrument dinyatakan valid apabila nilai koefisien korelasi $\geq 0,3$. Instrument dikatakan reliabel apabila instrumen tersebut memiliki kesamaan data dalam waktu yang berbeda. Suatu instrumen dinyatakan reliabel bila koefisien reliabilitas minimal 0,6.

\section{HASIL PENELITIAN DAN PEMBAHASAN}

Karakteristik responden diklasifikasikan kedalam ketergori demografi seperti jenis kelamin, usia, pekerjaan, dan pendapatan per bulan.

Tabel 3. memperlihatkan bahwa responden pada penelitian ini didominasi oleh wanita sebanyak 73 orang dengan persentase sebesar 52,1 persen, sedangkan responden berjenis kelamin pria sebanyak 67 orang dengan persentase 47,9 persen. Untuk variabel klasifikasi usia, kelompok usia $17-22$ tahun memiliki persentase tertinggi yakni sebesar 43,6 persen dengan jumlah responden mencapai 61 orang, sedangkan persentase terendah adalah kelompok usia 38 - 42 tahun sebesar 3,6 persen. Untuk klasifikasi responden berdasarkan pekerjaan, responden yang berprofesi sebagai pegawai swasta paling banyak ditemui dalam penelitian ini dengan persentase sebesar 42,1 persen. Pada klasifikasi pendapatan per bulan, 
responden dengan pendapatan antara Rp. 3.000.000 hingga Rp. 4.999 .999 memiliki persentase tertinggi yakni sebesar 25 persen, sedangkan kelompok pendapatan dengan persentase terendah adalah kelompok responden dengan pendapatan per bulan Rp. 9.000 .000 keatas sebesar 5 persen.

Tabel 3.

Karakteristik Responden

\begin{tabular}{|c|c|c|c|c|}
\hline No. & Variabel & Klasifikasi & $\begin{array}{l}\text { Jumlah } \\
\text { (Orang) }\end{array}$ & $\begin{array}{c}\text { Persentase } \\
(\%)\end{array}$ \\
\hline \multirow{2}{*}{1.} & \multirow{2}{*}{ Jenis Kelamin } & Pria & 67 & 47,9 \\
\hline & & Wanita & 73 & 52,1 \\
\hline \multirow{7}{*}{2.} & \multirow{7}{*}{ Usia } & Jumlah & 140 & 100 \\
\hline & & $17-22$ tahun & 61 & 43,6 \\
\hline & & $23-27$ tahun & 36 & 25,7 \\
\hline & & $28-32$ tahun & 25 & 17,9 \\
\hline & & $33-37$ tahun & 13 & 9,3 \\
\hline & & $38-42$ tahun & 5 & 3,6 \\
\hline & & Jumlah & 140 & 100 \\
\hline \multirow{6}{*}{3.} & \multirow{6}{*}{ Pekerjaan } & Pelajar/Mahasiswa & 50 & 35,7 \\
\hline & & Pegawai Negeri & 7 & 5,0 \\
\hline & & Pegawai Swasta & 59 & 42,1 \\
\hline & & Pengusaha/Wirausaha & 20 & 14,3 \\
\hline & & Profesional & 3 & 2.1 \\
\hline & & Lainnya & 1 & 0,7 \\
\hline \multirow{8}{*}{4.} & \multirow{8}{*}{ Pendapatan/bulan } & Jumlah & 140 & 100 \\
\hline & & $<$ Rp. 1.000 .000 & 30 & 21,4 \\
\hline & & Rp. 1.000 .000 - Rp. 2.999 .999 & 34 & 24,3 \\
\hline & & Rp. 3.000.000 - Rp. 4.999 .999 & 35 & 25,0 \\
\hline & & Rp. 5.000 .000 - Rp. 6.999 .999 & 20 & 14,3 \\
\hline & & Rp. 7.000.000 - Rp. 8.999.999 & 14 & 10,0 \\
\hline & & $\geq$ Rp. 9.000 .000 & 7 & 5,0 \\
\hline & & Jumlah & 140 & 100 \\
\hline
\end{tabular}

Sumber: Data Diolah, 2018

Hasil pengujian validitas yang ditunjukkan oleh Tabel 4. memperlihatkan nilai dari masing-masing instrumen yang digunakan lebih besar dari 0,3. Artinya seluruh instrumen dalam penelitian ini dapat dikatakan valid.

Tabel 5. memperlihatkan bahwa nilai cronbanch's alpha untuk masingmasing variabel $\geq 0,6$, ini berarti alat ukur dari instrumen yang digunakan akan memberikan hasil yang cenderung konsisten bila digunakan kembali untuk meneliti objek yang sama.

Berdasarkan hasil analasis yang telah dilakukan, maka persamaan regresi yang dapat dibentuk adalah sebagai berikut.

$$
\begin{array}{llll}
\mathrm{Y} & =0,472 \mathrm{X}_{1}+0,395 \mathrm{X}_{2}-0,295 \mathrm{X}_{3} \ldots \ldots \ldots \ldots \\
\mathrm{S}(\beta)=(0,083) & (0,093) & (0,062) \\
\mathrm{t} & =(5,699) & (4,585) & (-5,037) \\
\mathrm{Sig} & =(0,000) & (0,000) & (0,000) \\
\mathrm{R}^{2} & =0,595 & \mathrm{~F}=66,498 & \mathrm{Sig}=0,000
\end{array}
$$


Nilai $F_{\text {hitung }}$ sebesar 66,498 dengan signifikansi sebesar $0,000<0,05$, maka dapat disimpulkan bahwa gaya hidup $\left(\mathrm{X}_{1}\right)$, perceived benefit $\left(\mathrm{X}_{2}\right)$, dan perceived risk $\left(\mathrm{X}_{3}\right)$ berpengaruh secara simultan terhadap niat menggunakan $(\mathrm{Y})$ kartu kredit. Koefisien determinasi atau $\mathrm{R}^{2}=0,595$, mempunyai arti bahwa 59,5 persen variasi niat menggunakan kartu kredit dipengaruhi oleh variasi gaya hidup $\left(\mathrm{X}_{1}\right)$, variasi perceived benefit $\left(\mathrm{X}_{2}\right)$, dan variasi perceived risk $\left(\mathrm{X}_{3}\right)$, sedangkan sisanya 40,5 persen dipengaruhi oleh faktor lain diluar model yang digunakan dalam penelitian ini.

Tabel 4.

Hasil Uji Validitas

\begin{tabular}{|c|c|c|c|c|}
\hline No. & Variabel & Indikator & $\begin{array}{c}\text { Koefisien } \\
\text { Korelasi }\end{array}$ & Ket. \\
\hline \multirow{4}{*}{1.} & \multirow{5}{*}{ Gaya Hidup } & Peduli personal image & 0,631 & Valid \\
\hline & & Kemudahan dalam aktivitas bertransaksi & 0,805 & Valid \\
\hline & & Rasa bangga untuk menggunakan & 0,933 & Valid \\
\hline & & $\begin{array}{l}\text { Meningkatkan keyakinan atas kemampuan } \\
\text { finansial }\end{array}$ & 0,925 & Valid \\
\hline \multirow{8}{*}{2.} & & Mengangkat status sosial & 0,904 & Valid \\
\hline & \multirow{7}{*}{ Perceived Benefit } & Meningkatkan kinerja & 0,792 & Valid \\
\hline & & Meningkatkan produktifitas & 0,813 & Valid \\
\hline & & Lebih efektif dari uang tunai & 0,904 & Valid \\
\hline & & Lebih efisien dari uang tunai & 0,810 & Valid \\
\hline & & Cadangan dana & 0,864 & Valid \\
\hline & & Fleksibel & 0,723 & Valid \\
\hline & & Fasilitas pembelian & 0,735 & Valid \\
\hline \multirow{4}{*}{3.} & \multirow{4}{*}{ Perceived Risk } & Risiko cyber crime carding & 0,822 & Valid \\
\hline & & Peningkatan jumlah pengeluaran & 0,950 & Valid \\
\hline & & Kontrol diri terhadap pengeluaran & 0,943 & Valid \\
\hline & & Terbelit hutang yang tinggi & 0,839 & Valid \\
\hline \multirow{3}{*}{4.} & \multirow{3}{*}{ Niat Menggunakan } & Niat transaksional & 0,913 & Valid \\
\hline & & Niat eksploratif & 0,855 & Valid \\
\hline & & Niat preferensial & 0,949 & Valid \\
\hline
\end{tabular}

Sumber: Data Diolah, 2018

Tabel 5.

Hasil Uji Reliabilitas

\begin{tabular}{clcc}
\hline No. & Variabel & Cronbanch's Alpha & Ket. \\
\hline 1. & Gaya Hidup & 0,892 & Reliabel \\
2. & Perceived Benefit & 0,910 & Reliabel \\
3. & Perceived Risk & 0,912 & Reliabel \\
4. & Niat Menggunakan & 0,919 & Reliabel \\
\hline
\end{tabular}

Sumber: Data Diolah, 2018

Berdasarkan hasil uji Kolmogrov-Smirnov Model didapatkan hasil Sig (2tailed) sebesar 0,947, lebih besar dari taraf signifikansi 5 persen. Artinya, model regresi yang digunakan pada penelitian ini berdistribusi normal. 
Tabel 6.

Hasil Uji Normalitas

\begin{tabular}{llr}
\hline & & $\begin{array}{c}\text { Unstandardiz } \\
\text { ed Residual }\end{array}$ \\
\hline $\mathrm{N}$ & Mean & 140 \\
Normal Parameters & Std. Deviation & 0,000000 \\
& Absolute & 0,59227486 \\
Most Extreme & Positive & 0,044 \\
Differences & Negative & 0,035 \\
& & $-0,044$ \\
Kolmogorov-Smirnov Z & & 0,523 \\
Asymp. Sig. (2-tailed) & & 0,947 \\
\hline Sumber: Data Diolah, 2018 & &
\end{tabular}

Sumber: Data Diolah, 2018

Tabel 7. memperlihatkan bahwa nilai VIF dari masing-masing variabel bebas kurang dari 10, yakni variabel gaya hidup $\left(\mathrm{X}_{1}\right)$ memiliki nilai VIF $=2,304<$ 10 , variabel perceived benefit $\left(\mathrm{X}_{2}\right)$ memiliki nilai $\mathrm{VIF}=2,288<10$, variabel perceived risk memiliki nilai VIF $=1,150<10$. Ini membuktikan bahwa model regresi pada penelitian ini tidak mengalami gejala multikolinieritas.

\begin{tabular}{lc}
\multicolumn{2}{c}{ Tabel 7. } \\
\multicolumn{2}{c}{ Hasil Uji Multikolinieritas } \\
\hline \multicolumn{1}{c}{ Variabel Bebas } & VIF \\
\hline Gaya Hidup $\left(\mathrm{X}_{1}\right)$ & 2,304 \\
Perceived Benefit $\left(\mathrm{X}_{2}\right)$ & 2,488 \\
Perceived Risk $\left(\mathrm{X}_{3}\right)$ & 1,150 \\
\hline Sumber: Data Diolah, 2018 &
\end{tabular}

Berdasarkan hasil uji statistik, dapat diketetahui bahwa nilai signifikansi masing-masing variabel bebas berada diatas 0,05 , yakni variabel gaya hidup $\left(\mathrm{X}_{1}\right)$ memiliki nilai sig. $=0,076>0,05$, variabel perceived benefit $\left(\mathrm{X}_{2}\right)$ memiliki nilai sig. $=0.782>0,05$, variabel perceived risk $\left(\mathrm{X}_{3}\right)$ memiliki nilai sig. $=0,194>0,05$. Hasil ini membuktikan bahwa model regresi pada penelitian ini bebas dari masalah heteroskedastisitas.

\section{Tabel 8.}

Hasil Uji Heteroskedastisitas

\begin{tabular}{lcc}
\hline \multicolumn{1}{c}{ Variabel Bebas } & $\mathbf{t}$ & Sig. \\
\hline Gaya Hidup $\left(\mathrm{X}_{1}\right)$ & $-1,786$ & 0,076 \\
Perceived Benefit $\left(\mathrm{X}_{2}\right)$ & 0,277 & 0,782 \\
Perceived Risk $\left(\mathrm{X}_{3}\right)$ & $-1,306$ & 0,194 \\
\hline Sumber: Data Diolah, 2018 & &
\end{tabular}

Uji t digunakan untuk menguji variabel-variabel bebas secara individual berpengaruh terhadap variabel terikat. Taraf signifikansi dalam pengujian ini sebesar $\alpha=0,05$. Hipotesis yang diajukan dapat diterima bila nilai signifikansi variabel bebas kurang dari $\alpha=0,05$. 
Tabel 9.

Hasil Analisis Uji t

\begin{tabular}{lccc}
\hline \multicolumn{1}{c}{ Variabel } & thitung & Sig. & Hasil hipotesis \\
\hline Gaya Hidup $\left(\mathrm{X}_{1}\right)$ & 5,699 & 0,000 & $\mathrm{H}_{1}$ diterima \\
Perceived Benefit $\left(\mathrm{X}_{2}\right)$ & 4,585 & 0,000 & $\mathrm{H}_{2}$ diterima \\
Perceived Risk $\left(\mathrm{X}_{3}\right)$ & $-5,037$ & 0,000 & $\mathrm{H}_{3}$ diterima \\
\hline
\end{tabular}

Sumber: Data Diolah, 2018

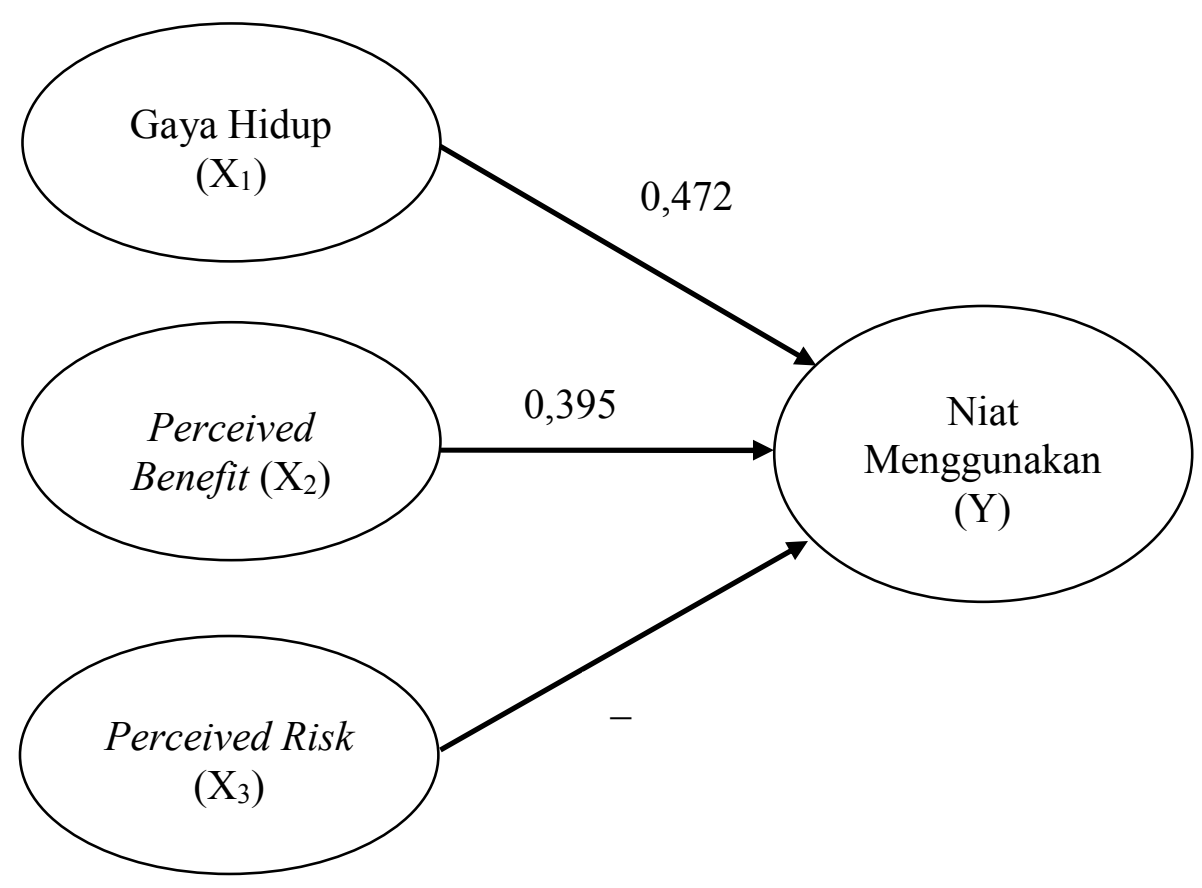

Sumber: Data Diolah, 2018

Gambar 1. Pengaruh Gaya Hidup, Perceived Benefit, dan Perceived Risk Terhadap Niat Menggunakan

Berdasarkan hasil pengujian statistik diperoleh nilai sig. $\mathrm{t}$ sebesar 0,000 dengan nilai koefisien beta sebesar 0,472 , maka $\mathrm{H}_{1}$ diterima dan dapat disimpulkan bahwa terdapat pengaruh positif signifikan antara gaya hidup terhadap niat menggunakan yang menunjukkan semakin tinggi gaya hidup seseorang maka akan meningkatkan niat menggunakan kartu kredit.

Penelitian ini mendapat hasil positif karena pengaruh dari indikator peduli personal image atau citra diri yang menghasilkan nilai rata-rata tanggapan responden tertinggi. Ini berarti ketertarikan responden untuk menggunakan kartu kredit didominasi oleh kelompok gaya hidup innovators, achievers, strivers, dan experiencers dimana gaya hidup ini sangat mementingkan citra diri dan penampilan yang nantinya memengaruhi niat mereka dalam penggunaan kartu kredit. Selain itu, sebagian besar responden merasa kurang yakin apabila menggunakan kartu kredit akan meningkatkan keyakinan atas kemampuan finansialnya yang dibuktikan pada indikator opini memiliki nilai rata-rata 
tanggapan terendah. Mereka merasa bahwa dibandingkan meningkatkan rasa percaya diri atas kemampuan finansial, penggunaan kartu kredit justru membantu mereka secara finansial terutama dalam keadaan atau situasi terdesak.

Hasil penelitian ini mendukung pernyataan Alam (2006) dimana kegiatan menggunakan kartu kredit dianggap bisa menunjukkan karakter, gengsi, citra diri dan keberhasilan ekonomi seseorang yang mengakibatkan gaya hidup diperkirakan dapat memengaruhi minat seseorang untuk menggunakan kartu kredit. Anggraini \& Soenhadji (2016) menjelaskan bahwa semakin tinggi gaya hidup seseorang maka kecenderungan menggunakan kartu kredit semakin kuat. Hasil serupa juga ditemukan pada penelitian yang dilakukan Suraputra \& Warmika (2017) yang menunjukan bahwa gaya hidup berpengaruh positif signifikan terhadap niat pembelian sepeda motor sport Honda di Kota Denpasar. Penelitian lain yang dilakukan oleh Indrayani \& Nurcaya (2014) juga membuktikan bahwa terdapat pengaruh positif signifikan antara variabel gaya hidup terhadap niat beli handphone Samsung Galaxy di Kota Denpasar dimana ketertarikan konsumen terhadap handphone Samsung Galaxy lebih banyak terhadap apalikasi yang tersedia dan fitur yang beragam yang akan memberikan hiburan atau kesenangan tersendiri.

Hasil pengujian statistik mendapatkan nilai sig. $t$ sebesar 0,000 dengan nilai koefisien beta sebesar 0,395 , maka $\mathrm{H}_{2}$ diterima dan dapat disimpulkan bahwa terdapat pengaruh positif signifikan antara perceived benefit terhadap niat menggunakan. Hasil tersebut menunjukkan semakin tinggi perceived benefit yang didapat maka akan meningkatkan niat seseorang untuk menggunakan kartu kredit.

Hasil penelitian ini dipengaruhi oleh tanggapan responden yang positif terhadap perceived benefit dari penggunaan kartu kredit terutama pada indikator cadangan dana yang berarti manfaat terbesar yang diharapkan responden dalam penggunaan kartu kredit adalah pemberian cadangan dana yang membantu meringankan beban finansial disituasi darurat. Hasil dari manfaat ini dapat membentuk dan meningkatkan keinginan responden untuk menggunakan kartu kredit. Disamping itu, penggunaan kartu kredit dirasa kurang efektif bagi sebagian besar responden yang ditandai dengan indikator enhances effectiveness memperoleh nilai rata-rata tanggapan terendah. Kondisi ini disebabkan oleh kurangnya pemahaman responden akan manfaat dan penggunaan kartu kredit secara tepat sehingga merasa bahwa uang tunai jauh lebih efektif dibandingkan kartu kredit.

Hasil penelitian ini sesuai dengan hasil penelitian sebelumnya yang dilakukan oleh oleh Lee (2008) yang memaparkan bahwa niat menggunakan online banking secara positif signifikan dipengaruhi oleh perceived benefit. Hasil ini menyiratkan bahwa perceived benefit merupakan prediktor positif yang paling penting dalam membentuk niat untuk menggunakan perbankan online. Hasil serupa juga ditemukan oleh Rochmawati (2013) yang membuktikan bahwa perceived benefit berpengaruh positif signifikan terhadap niat menggunakan kartu kredit dimana mayoritas responden menggunakan kartu kredit untuk membeli kebutuhan sehari-hari, belanja bulanan dan untuk perjalanan/travel, membeli barang elektronik, dan membayar kebutuhan yang bersifat mendadak serta dapat menghemat waktu jika menggunakan kartu kredit. Kirana \& Kerti Yasa (2013) 
dalam penelitiannya menyatakan perceived benefit memiliki pengaruh positif signifikan terhadap niat menggunakan kartu kredit di Kota Denpasar. Pada penelitian tersebut, perceived benefit berkaitan dibandingkan dengan uang tunai menggunakan kartu kredit akan memberikan nilai yang baik, merasa nyaman menggunakan kartu kredit dan merasa lebih mudah untuk melakukan transaksi menggunakan kartu kredit memiliki pengaruh yang tinggi terhadap niat menggunakan kartu kredit di Kota Denpasar.

Hasil pengujian statistik diperoleh nilai sig. t sebesar 0,000 dengan nilai koefisien beta sebesar $-0,295$, maka $\mathrm{H}_{3}$ diterima dan dapat disimpulkan bahwa terdapat pengaruh negatif signifikan antara perceived risk terhadap niat menggunakan. Hasil tersebut menunjukkan semakin tinggi perceived risk yang didapat maka akan menurunkan niat seseorang untuk menggunakan kartu kredit.

Hasil penelitian ini dipengaruhi oleh indikator financial risk khususnya pada pernyataan mengenai rasa takut responden terbelit hutang yang tinggi jika menggunakan kartu kredit. Sebagian besar responden pada penelitian ini berpendapat bahwa niat mereka untuk menggunakan kartu kredit terhalangi oleh rasa takut untuk terbelit hutang dan berdampak pada bertambahnya beban finansial mereka. Selain itu, risiko ciber crime carding pada kartu kredit dinilai cukup tinggi bagi sebagian responden meskipun indikator ini memiliki nilai ratarata tanggapan terendah, namun cukup untuk menjadi salah satu penyebab ketakutan dan keengganan responden untuk menggunakan kartu kredit.

Hasil penelitian ini didukung oleh penelitian yang dilakukan oleh Quan \& Nam (2017) yang membuktikan bahwa faktor perceived risk berpengaruh negatif signifikan pada niat untuk menggunakan kartu kredit. Penelitian tersebut menyebutkan ketika menggunakan kartu kredit, konsumen mungkin menghadapi situasi tak terduga seperti ketidakmampuan untuk membayar tagihan atau membayar transaksi yang tidak mereka lakukan yang disebut dengan risiko kartu kredit. Selaras dengan penelitian Kim et al. (2008) yang menyatakan perceived risk secara negatif memengaruhi niat konsumen untuk membeli secara online. Juniwati (2014) pada penelitiannya juga menyatakan niat untuk berbelanja online dipengaruhi secara negatif oleh perceived risk. Hasil serupa juga ditemukan oleh Farzianpour et al. (2014) yang membuktikan bahwa perceived risk berpengaruh negatif signifikan terhadap niat menggunakan layanan perbankan online.

Berdasarkan pembahasan hasil penelitian diatas, maka implikasi dari penelitian ini adalah pengembangan konsep yang berkaitan dengan gaya hidup, perceived benefit, perceived risk, dan niat menggunakan kartu kredit. Penelitian ini memperkaya bukti empiris hubungan gaya hidup, perceived benefit, perceived risk, dan niat menggunakan. Hasil dari penelitian ini menunjukkan pengaruh antar variabel seperti pengaruh antara variabel gaya hidup terhadap variabel niat menggunakan. Apabila gaya hidup yang dimiliki oleh seseorang semakin baik atau tinggi, maka akan mampu memberikan kontribusi yang signifikan dalam meningkatkan niat seseorang untuk menggunakan kartu kredit. Selanjutnya, terdapat pengaruh antara variabel perceived benefit terhadap niat menggunakan. Penelitian ini menunjukkan apabila nilai perceived benefit semakin tinggi, maka akan mampu memberikan sebuah kontribusi yang signifikan dalam meningkatkan niat konsumen untuk menggunakan kartu kredit. Semakin banyak manfaat yang 
bisa dirasakan, maka semakin kuat pula niat untuk menggunakan kartu kredit. Kemudian, terdapat pengaruh antara variabel perceived risk terhadap niat menggunakan. Apabila semakin tinggi perceived risk yang dirasakan maka akan menurunkan niat seseorang untuk menggunakan kartu kredit. Implikasi dari penelitian ini dapat menggambarkan bahwa gaya hidup, perceived benefit, perceived risk mampu memengaruhi niat menggunakan.

Selain itu, penelitian ini diharapkan dapat memberikan implikasi kepada pihak bank sebagai penerbit kartu kredit akan pentingnya gaya hidup yang dianut konsumen, perceived benefit, dan perceived risk yang dapat memengaruhi niat konsumen untuk menggunakan kartu kredit di Indonesia. Hubungan antara gaya hidup dan niat menggunakan kartu kredit dapat memberikan informasi bagi pihak bank dalam mensegmentasi konsumen berdasarkan gaya hidup yang dianut. Konsumen dengan gaya hidup innovators, achievers, strivers, dan experiencers dapat menjadi kelompok konsumen yang potensial untuk ditargetkan menjadi nasabah kartu kredit. Disamping itu, hubungan antara perceived benefit dan perceived risk dengan niat menggunakan kartu kredit dapat menjadi bahan pertimbangan bagi pihak bank dalam menetapkan kebijakan dan memasarkan kartu kredit yang sesuai kebutuhan dan keinginan konsumen.

\section{SIMPULAN}

Berdasarkan hasil penelitian yang telah diuraikan, maka simpulan yang didapat adalah gaya hidup berpengaruh positif signifikan terhadap niat menggunakan kartu kredit. Artinya, semakin tinggi gaya hidup seseorang maka semakin tinggi pula niat menggunakan kartu kredit. Perceived benefit berpengaruh positif signifikan terhadap niat menggunakan kartu kredit. Artinya, semakin tinggi perceived benefit maka semakin tinggi juga niat menggunakan kartu kredit. Perceived risk berpengaruh negatif signifikan terhadap niat menggunakan kartu kredit. Artinya, semakin tinggi perceived risk maka semakin rendah niat menggunakan kartu kredit.

Berdasarkan simpulan yang telah dijabarkan diatas maka dapat diajukan beberapa saran yakni, pihak bank hendaknya dapat memberikan berbagai kampanye positif seperti seminar, sosialisasi, penyuluhan, publikasi, dan promosi yang menarik, informatif, dan mudah dipahami melalui berbagai media seperti website resmi, e-mail, sms, ataupun media sosial tentang penggunaan kartu kredit secara bijak yang dapat disesuaikan dengan kemampuan membayar konsumen. Pemberian berbagai penawaran menarik berupa reward point, diskon, cashback atau suku bunga yang rendah dapat membantu mengurangi beban biaya konsumen sehingga konsumen merasa percaya diri akan kemampuan finansialnya dan niat menggunakan kartu kredit dapat ditingkatkan. Memperluas jangkauan merchant yang mempermudah konsumen untuk melakukan transaksi dimana pun, baik di dalam negeri maupun di luar negeri guna meyakinkan konsumen akan manfaat dan keuntungan kartu kredit sebagai pengganti uang tunai dalam kegiatan transaksi sehari-hari yang bernominal kecil sehingga kartu kredit dapat digunakan secara efektif yang nantinya akan meningkatkan minat konsumen untuk menggunakan kartu kredit. 
Selain itu, pihak perbankan sebaiknya bekerjasama dengan pihak asuransi untuk mengantisipasi dampak dari risiko yang terjadi dan meningkatkan pengawasan dalam keamanan penggunaan kartu kredit seperti teknologi chip pada kartu kredit guna meminimalisir kasus pembobolan dan penyalahgunaan kartu kredit. Perlunya pemberian edukasi penggunaan layanan kartu kredit yang aman kepada konsumen untuk menghindari terjadinya risiko yang diakibatkan oleh kelalaian pengguna layanan seperti kehilangan kartu kredit atau dicuri, sehingga minat konsumen dalam menggunakan kartu kredit dapat ditingkatkan.

\section{REFERENSI}

Alam, V. S. P. (2006). Hubungan Antara Gaya Hidup Achievers Dengan Minat Menggunakan Kartu Kredit Pada Pegawai Wanita Sekretariat Daerah Propinsi Jawa Tengah. Retrieved September 1, 2018, from http://eprints.undip.ac.id/10354/

Amin, H. (2007). An analysis of mobile credit card usage intentions. Information Management \& Computer Security, 15(4), 260-269. https://doi.org/10.1108/09685220710817789

Andryanto, R. (2016). Pengaruh Kepercayaan, Persepsi Manfaat, Dan Persepsi Kemudahan Penggunaan Terhadap Minat Beli Di Toko Online (Studi Empiris Yang Dilakukan Pada Olx.Co.Id Di Yogyakarta). Retrieved September 1, 2018, from https://eprints.uny.ac.id/41480/

Anggraini, R., \& Soenhadji, I. M. (2016). Pengaruh Gaya Hidup dan Pemanfaatan Teknologi ( E-Banking ) Terhadap Kepemilikan Kartu Kredit Serta Dampaknya pada Sikap Pengguna. In Seminar Nasional Aplikasi Teknologi Informasi (SNATi) 2016.

Asbar, Y. (2014). Analysis Of The Effect Of Perceived Of Usefulness, Perceived Ease Of Use, Perceived Lifestyle And Attitudes Toward On Credit Card Usage. In Prosiding Seminar Nasional Ekonomi 2014 (pp. 603-613). Fakultas Ekonomi Universitas Malikussaleh.

Astari, R. W. (2016). 5 Alasan Orang Takut Memiliki Kartu Kredit. Retrieved February 5, 2019, from https://kreditgogo.com/artikel/Kartu-Kredit/5Alasan-Orang-Taku t-Memiliki-Kartu-Kredit.html

Bank Indonesia. (2009). Laporan Sistem Pembayaran dan Pengedaran Uang. Retrieved from https://www.bi.go.id/id/publikasi/sistempembayaran/perkembangan/Documents/ed236469ef244a4b927dde0175122b edLSPPU2009.pdf

Bank Indonesia. (2010). Karakteristik Kartu yang Diterbitkan Perbankan. Retrieved January 14, 2019, from https://www.bi.go.id/id/sistem- 
pembayaran/instrumen-nontunai/kartu/Contents/Default.aspx

Bank Indonesia. (2012). Gerai Info Edisi 23, Februari 2012, Tahun 3. Bank Indonesia, 1-12. Retrieved from https://www.bi.go.id/id/publikasi/geraiinfo/Pages/gi_2312.aspx

Bank Indonesia. (2019). Statistik Sistem Pembayaran, Alat Pembayaran dengan Menggunakan Kartu (APMK), Jumlah APMK Beredar. Retrieved January 23, 2019, from https://www.bi.go.id/id/statistik/sistempembayaran/apmk/contents/jumlah apmk beredar.aspx

Bernthal, M. J., Crockett, D., \& Rose, R. L. (2005). Credit Cards as Lifestyle Facilitators. Journal of Consumer Research, 32(1), 130-145. https://doi.org/10.1086/429605

Cheema, U., Rizwan, M., Jalal, R., Durrani, F., \& Sohail, N. (2013). The Trend of Online Shopping in 21st Century: Impact of Enjoyment in TAM Model. Asian Journal of Empirical Research, 3(2), 131-140.

Dewi, N. M. A. P., \& Warmika, I. G. K. (2016). Peran persepsi kemudahan penggunan, persepsi manfaat dan perspsi resiko terhadap niat menggunakan. E-Jurnal Manajemen Unud, 5(4), 2606-2636.

Disa, S. M., \& Kesuma, T. M. (2016). Pengaruh Persepsi Risiko, Persepsi Manfaat, Dan Kepercayaan Terhadap Niat Pembelian Konsumen Di Portal E-Commerce. Jurnal Ilmiah Mahasiswa Ekonomi Manajemen, 1(2), 323-344.

Farzianpour, F., Pishdar, M., Shakib, M. D., \& Toloun, M. R. S. H. (2014). Consumers' perceived risk and its effect on adoption of online banking services. American Journal of Applied Sciences, 11(1), 47-56. https://doi.org/10.3844/ajassp.2014.47.56

Ferdinand, A. (2014). Metode Penelitian Manajemen: Pedoman Penelitian Untuk Penulisan Skripsi, Tesis, dan Desertasi Ilmu Manajemen. Semarang: Badan Penerbit Universitas Diponegoro.

Fernanda, I. V. (2016). Pengaruh Persepsi Harga, Persepsi Kualitas, Persepsi Risiko Terhadap Niat Pembelian Produk Merek Toko Indomaret Di Surabaya. Artikel Ilmiah Sekolah Tinggi Ilmu Ekonomi Perbanas Surabaya.

Gunawan, M., \& Linawati, N. (2013). Analisa Faktor yang Berhubungan dengan Pertimbangan Cost and Benefit Kartu Kredit. Finesta, 1(2), 79-84. Retrieved from http://studentjournal.petra.ac.id/index.php/manajemenkeuangan/article/view/1177 
Indrayani, L., \& Nurcaya, I. N. (2014). Peran Persepsi Kualitas Produk Dalam Memediasi Pengaruh Gaya Hidup Terhadap Niat Beli Handphone Samsung Galaxy Di Kota Denpasar. E-Jurnal Manajemen Unud, 3(4), 885-901.

Jogiyanto, H. M. (2007). Sistem Informasi Keperilakuan. Yogyakarta: Erlangga. Juniwati. (2014). Influence of Perceived Usefulness, Ease of Use, Risk on Attitude and Intention to Shop Online. European Journal of Business and Management, 6(27), 2222-2839.

Kim, D. J., Ferrin, D. L., \& Rao, H. R. (2008). A trust-based consumer decisionmaking model in electronic commerce: The role of trust, perceived risk, and their antecedents. Decision Support Systems, 44(2), 544-564. https://doi.org/10.1016/j.dss.2007.07.001

Kirana, I. D. A. I., \& Yasa, N. N. K. (2013). Peran Gender Dalam Memoderasi Pengaruh Perceived Benefit dan Perceived Cost Terhadap Niat Menggunakan Kartu Kredit Di Kota Denpasar. E-Jurnal Manajemen Unud, 2(11), 1418-1433.

Kotler, P., \& Keller, K. L. (2016). Marketing Management Global Edition15th Edition. (Vol. 15E). https://doi.org/10.1080/08911760903022556

Lee, M. C. (2008). Factors influencing the adoption of internet banking: An integration of TAM and TPB with perceived risk and perceived benefit. Electronic Commerce Research and Applications, 8(3), 130-141. https://doi.org/10.1016/j.elerap.2008.11.006

Lestari, B. A., Suharjo, B., \& Muflikhati, I. (2017). Minat Kepemilikan Kartu Kredit (Studi Kasus Kota Bogor). Jurnal Aplikasi Bisnis Dan Manajemen, 3(1), 143-151. https://doi.org/10.17358/jabm.3.1.143

Lubis, A. F., \& Lubis, I. (2012). Analisis Perilaku Masyarakat Muslim Terhadap Penggunaan Kartu Kredit Di Kota Medan. Jurnal Ekonomi Dan Keuangan, $1(1), 22-35$.

Mowen, J. C., \& Minor, M. (2002). Perilaku Konsumen Jilid 1 (Edisi Keli). Jakarta: Erlangga.

Nora, L., \& Minarti, N. S. (2016). The role of religiosity, lifestyle, attitude as determinant purchase intention. The 2nd International Multidisciplinary Conference 2016, 1(1), 135-148.

Pramono, B., Yanuarti, T., Purusitawati, P. D., \& D.K., Y. T. E. (2006). Dampak Pembayaran Non Tunai Terhadap Perekonomian dan Kebijakan Moneter. Working Paper Bank Indonesia. 
Qing, P., Lobo, A., \& Chongguang, L. (2012). The impact of lifestyle and ethnocentrism on consumers' purchase intentions of fresh fruit in China. Journal of Consumer Marketing, 29(1), 43-51. https://doi.org/10.1108/07363761211193037

Quan, V. D. H., \& Nam, T. H. (2017). Perceived Risk and the Intention to use Credit Cards. International Research Journal of Finance and Economics, (159), 77-85.

Rahayu, F., Irmawati, \& Hermuningsih, S. (2011). Perkembangan Kartu Kredit di Indonesia. Jurnal Manajemen, 1(1), 5-13. https://doi.org/10.26460/jm.v1i1.129

Rashidi, H. (2015). Lifestyle and Youth : Identifying Lifestyle among Women in Mahabad, Iran. European Online Journal of Natural and Social Sciences, 4(1), 1052-1060.

Rochmawati, S. (2013). Pengaruh Sikap, Norma Subjektif, Kontrol Perilaku Persepsian, Persepsi Risiko, Persepsi Kebermanfaatan Terhadap Niat Penggunaan Kartu Kredit. Jurnal Ilmiah Mahasiswa FEB Universitas Brawijaya Malang, 1(2), 1-14.

Sayono, J. A., Sumarwan, U., Azam, N. A., \& Hartoyo. (2009). Analisis FaktorFaktor Yang Mempengaruhi Kepemilikan, Penggunaan, Pembayaran Dan Peluang Terjadinya Gagal Bayar Dalam Bisnis Kartu Kredit. Jurnal Ekonomi \& Bisnis, 3(1), 61-80.

Schiffman, L., \& Kanuk, L. L. (2008). Perilaku Konsumen (Edisi Ketu). Jakarta: Indeks.

Strategic Business Insights. (2015). US Framework and VALS Types. Retrieved October 7, 2018, from http://www.strategicbusinessinsights.com/vals/ustypes.shtml

Suraputra, I. M. W., \& Warmika, I. G. K. (2017). Pengaruh Gaya Hidup Terhadap Niat Pembelian Sepeda Motor Sport Honda Yang Dimediasi Oleh Sikap. EJurnal Manajemen Unud, 6(1), 176-203.

Tim Inisiatif BI. (2006). Upaya Meningkatkan Penggunaan Alat Pembayaran Non Tunai Melalui Pengembangan E-Money. Working Paper Bank Indonesia, 48.

Venkatesh, V., \& Davis, F. D. (2000). A Theoretical Extension of the Technology Acceptance Model: Four Longitudinal Field Studies. Management Science, 46(2), 186-204. https://doi.org/10.1287/mnsc.46.2.186.11926

Wickramasinghe, V., \& Gurugamage, A. (2012). Effects of social demographic 
E-Jurnal Manajemen, Vol. 8, No. 11, 2019 : 6598-6617

attributes, knowledge about credit cards and perceived lifestyle outcomes on credit card usage. International Journal of Consumer Studies, 36(1), 80-89. https://doi.org/10.1111/j.1470-6431.2010.00993.x

Zaidi, S. D. A., Gondal, B. J., Yasmin, A., Urooj, M., \& Rizwan, M. (2014). Antecedents of Online Shopping Intention: A Study held in Pakistan. Journal of Sociological Research, 5(1), 231-247. https://doi.org/10.5296/jsr.v5i1.6564 